\title{
Framework for layout design of green field shipyard at falta
}

\begin{abstract}
The shipyard will be situated at Ramnagar in South 24 Parganas district of West Bengal in about 35,000 $\mathrm{m} 2$ on the bank of river Hugli stretching about $300 \mathrm{~m}$. Ships are playing in Navigation Channel of river Hugli between Sea \& Kolkata Port Trust. This shipyard is situated on the bank of this Navigation Channel. The distance of Kolkata Port Trust (KoPT) Navigation Channel from the land boundary is between $350-400 \mathrm{~m}$. Adequate draft is available in river Hugli near Falta point throughout the year for movement of Ships in KoPT navigation channel. The site is well connected by motorable roads to the city of Kolkata. The distance is about $43 \mathrm{~km}$ from the city (Kolkata). The objective of the present paper is to prepare a model design of layout of a shipyard at Greenfield Falta to fulfill the goal of Government of India to establish shipbuilding facility for future demand.
\end{abstract}

Volume 3 Issue 3 - 2017

\author{
Parimal Bhattacharya, ${ }^{\prime}$ Abhishek Roy, ${ }^{2}$ Achal \\ Garg $^{2}$ \\ 'Naval Architect, Keppel Offshore and Marine, India \\ ${ }^{2}$ Structural Engineer, Keppel Offshore and Marine, India
}

Correspondence: Achal Garg, Structural engineer, Keppel offshore and marine Ltd, Mumbai, India,

Email achalgarg_1992@yahoo.com

Received: July 03, 2017 | Published: September 12, 2017

Keywords: layout, manufacturing, navigation, shipyard

\section{Introduction}

In the Middle East and South Asia, growth in container port demand has accelerated in recent years. This has been driven by strong oil prices, a measure of deregulation and investment in the Indian subcontinent and the integration of the region into the major eastwest trades. Whilst demand is very strong in India, the capabilities of its ports and terminals remain limited, and the connectivity of these facilities with major hinterland markets is under mounting pressure. The planned major investment will need to be realized to accommodate anticipated growth, and coping with congestion will require a transformation of terminal productivity. For these reasons Indian Government is encouraging private \& public sector organizations to establish shipbuilding facility to fulfill the demand of commercial \& even defense ships.

\section{Basic design parameters and site conditions}

The objective of the project is to prepare a model design of layout of a shipyard at Greenfield Falta to fulfill the goal of Indian Government to establish shipbuilding facility for future demand. The proposed site is situated at Ramnagar in South 24 Parganas district of West Bengal \& the site is ideal for ship construction (Table 1). There is tidal effect on river water depth, the variation in tide during 2010 year is given in following (Figure 1).

Table I Tide at falta point during the year 2010

\begin{tabular}{llll}
\hline Month & Low water Height $[\mathrm{m}]$ & Mean water height $[\mathrm{m}]$ & High water height $[\mathrm{m}]$ \\
\hline I0-Jan & 6.43 & 3.6175 & 0.9 \\
I0-Feb & 6.52 & 3.665 & 0.81 \\
I0-Mar & 6.54 & 3.59 & 0.68 \\
I0-Apr & 6.46 & 3.775 & 0.98 \\
I0-May & 6.45 & 3.94 & 1.43 \\
I0-Jun & 6.74 & 4.125 & 1.51 \\
I0-Jul & 7.09 & 4.25 & 1.41 \\
10-Aug & 7.34 & 4.225 & 1.11 \\
10-Sep & 7.34 & 4.155 & 0.97 \\
10-Oct & 7.19 & 4.14 & 1.09 \\
10-Nov & 6.73 & 4.045 & 1.36 \\
10-Dec & 6.21 & 3.6925 & 1.4 \\
\hline
\end{tabular}




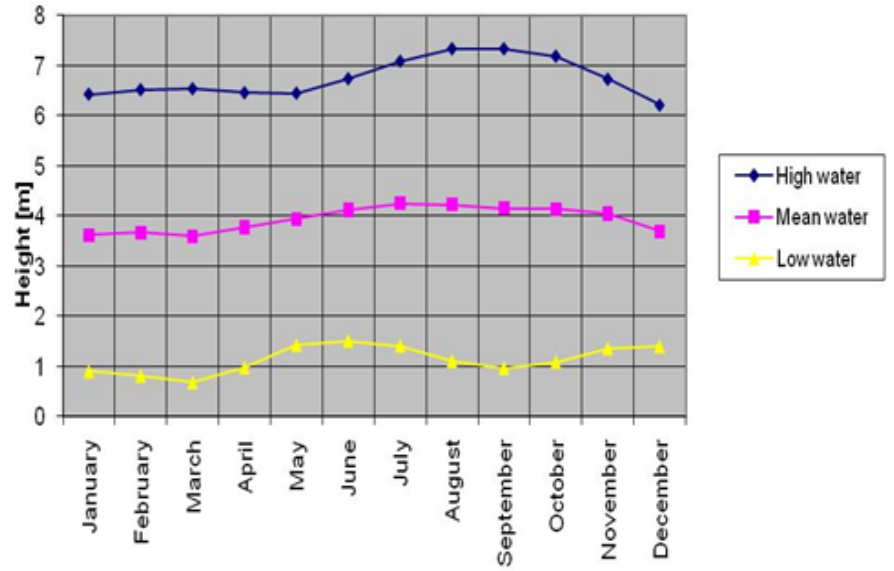

Figure I Tide at falta point during the year 2010.

\section{Detail dimension of offshore petrol vessel (OPV)}

a. Length (over all) $: 80.60 \mathrm{~m}$

b. Length in water line $: 74.40 \mathrm{~m}$

c. Beam moulded : $13.00 \mathrm{~m}$

d. Depth : $6.50 \mathrm{~m}$

e. Design draft : $3.80 \mathrm{~m}$

f. Speed $\min : 18.00 \mathrm{Knts}$

g. Crew : 64 Persons/36Persons

h. Range : $4400 \mathrm{Nm}$ at $18 \mathrm{Knts} / 10000 \mathrm{Nm}$ at $12 \mathrm{Knts}$ (Figure 2)

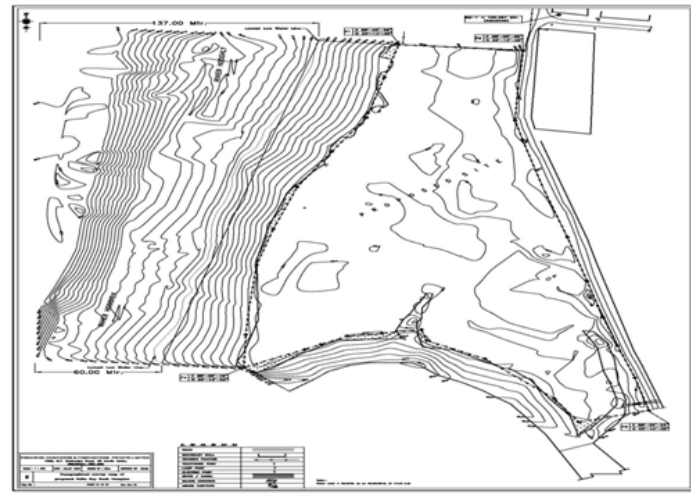

Figure 2 Survey drawing.

\section{Methodology}

\section{Survey of existing land}

A detail survey of existing land has already been carried out by some expert people to determine the contour of different parts of the existing land at Falta. A detail survey drawing has incorporated in the subsequent report.

\section{Literature survey for tide variation of river hugli at falta}

The water level of river Hugli near Falta is not maintaining same height throughout the year. For this reason a tidal variation chart has prepared with the help of Hugli River Tide Tables for Sagar, Gangra,
Haldia, Diamond Harbour, Mayapur \& Garden Reach (Kolkata)-2010, Published by Surveyor General of India.

\section{Study of modern facility at Shipyard}

A study has done on the facilities available at Goa Shipyard \& GRSE. Those information has used during design stage of the layout. Beside this few reference books \& soft survey data also used for the above purpose (Figures 3,4).

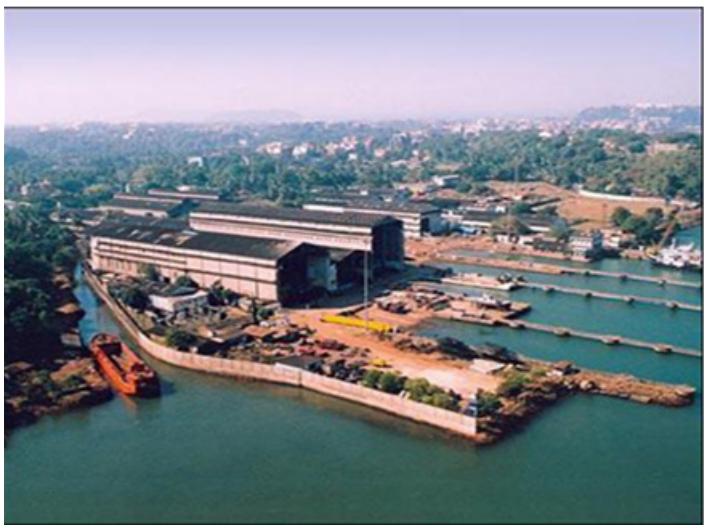

Figure 3 Facility available at goa shipyard.

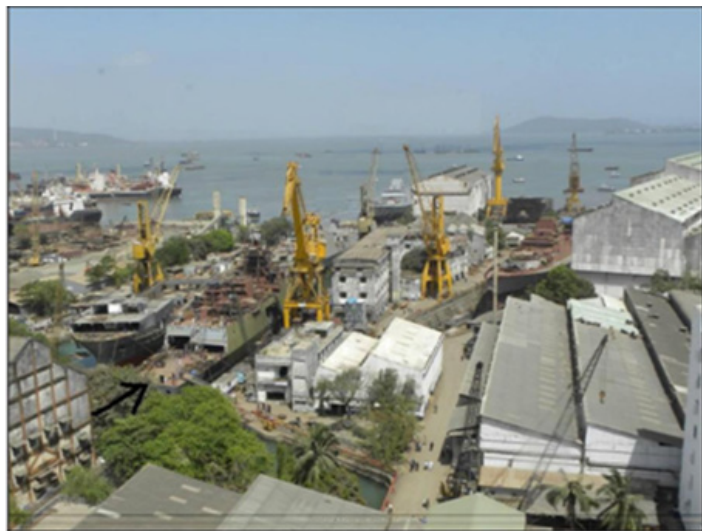

Figure 4 Facility available at GRSE.

\section{Planning for production capacity}

As per present site conditions \& facilities available it is assumed that the ideal production capacity for the site is as following:

\section{Large ship-3 No.s/Annum}

$\{82 \mathrm{M}(\mathrm{L}) \times 18 \mathrm{M}(\mathrm{B}) \times 3.8 \mathrm{M}(\mathrm{D})\}$ or $\{105 \mathrm{M}(\mathrm{L}) \times 30 \mathrm{M}(\mathrm{B}) \times 4.5 \mathrm{M}(\mathrm{D})\}$

\section{Small crafts - 24 Nos. I Annum}

$\{30 \mathrm{M}(\mathrm{L}) \times 10 \mathrm{M}(\mathrm{B}) \times 3 \mathrm{M}(\mathrm{D})\}$

\section{Planning for material movement}

A detail description on above subject has incorporated in the subsequent report.

\section{Design and description of facilities}

The various facilities and production shops, that are needed for a medium size shipyard have been properly laid out on the land available and shown in the drawing General Layout of Shipyard. The 
various jobs that are proposed to be undertaken in the proposed small shipyard are given below.

\section{Manufacturing activity}

Manufacturing of complete Ships or Boats constructed out of different materials like Steel/ Aluminum/FRP etc; the production of ships will be carried out as per modern shipbuilding practice by using different material handling equipment. Blocks will be fabricated and they will be erected in the block erection bay. Finally the completed ship will be launched from the launch way of the ship. Based on the geometry, land and river draft availability in the proposed location. It has been estimated (based on calculation) that it will be possible to manufacture vessels up to following broad dimensions:

i. Fine shaped (low block co-efficient) high speed military/ pleasure/passenger vessels of dimensions up to $82 \mathrm{~m}(\mathrm{~L}) \mathrm{x} 18 \mathrm{~m}(\mathrm{~B})$ $\mathrm{x} 3.8 \mathrm{~m}(\mathrm{~T})$

ii. High block co-efficient, fuller type ships for commercial purpose/ landing craft/Dredger/barges/port crafts etc. of dimensions up to $105 \mathrm{~m}(\mathrm{~L}) \times 30 \mathrm{~m}(\mathrm{~B}) \times 4.5 \mathrm{~m}(\mathrm{~T})$. Note: In all cases the launching weight of the vessel will not exceed 2000tonnes.

iii. Small boats of about 30M long made of Aluminum/GRP and launched in the adjoining Canal.

\section{Repair activity}

Repair activates will also be undertaken, at in the shipyard. For carrying out repair to the underwater hull, the ship will be pulled up by the winch plus cradle facilities which are used for launching and after completion of repair, the vessel will be put in the water by controlled method with the help of the cradle plus winch facility. For afloat, repair the pontoon assisted facilities created for outfitting purpose will be used. In future, when the outfitting jetty will be fully operational with the gates, by the canal side, the repair in afloat condition will also be carried out in that facility.

\section{Plate processing activity}

Plates and sections will be cleaned by shot blasting machine and painted and thereafter piece parts will be cut by CNC machine. These parts will then be supplied to various shops for carrying out manufacturing activities. The facilities are divided in various functional categories such as launch facilities, outfitting and repair facilities, production shops, various stores, and greenery. In the shipyard various types of launching facilities are proposed to be set up. Boats made of Aluminum/GRP of about $30 \mathrm{M}$ will be launched in controlled cradle and winch system onto the existing canal situated on the southern side of the shipyard.

\section{Launching facilities}

The vessel which will be manufactured in our proposed shipyard as indicated in earlier paragraphs will be launched in a controlled way by cradle and winch system. In this system the vessel movement is controlled by the winch and when the vessel will be fully water borne, the speed of the vessel will be very little and she can be taken over by tug and safely put alongside the pontoons located at one of the outfitting zone (depending on the size of the vessel) and properly tied up there. Under this scheme the launched vessel will never go inside the river channel which is between $350-450 \mathrm{~m}$ away from the land and $260 \mathrm{~m}$ away from the launch way end. We have carried out launching calculation for a standard fine ship (low block co-efficient) similar to military type offshore patrol vessel. It is concluded that if the OPV type vessel is launched from a traditional launching arrangement i.e. fixed way + sliding way, the speed of the launched ship will be zero after travel of $540 \mathrm{~m}$ measured from its original position which is $70 \mathrm{~m}$ from the eastern wall, if it is completely unaided. The vessel will be fully water borne (buoyant) after $116 \mathrm{~m}$ of travel. In practice however, when the vessel will be fully water borne, her anchors will be dropped and also the vessel will be tied with shore bollards in order to control her speed. In the situation, it is estimated that the total travel will be $400 \mathrm{~m}$. Tugs which will be standby will also take the control of the ship. Thus, even in conventional launching scheme, the total travel distance of the launched ship will limited to $400 \mathrm{~m}$. The calculation has been carried out based on a very fine military OPV. For fuller commercial ship (higher block coefficient), the in water resistance acting on the ship will be very high and the total travel length of such a ship will be limited $400 \mathrm{~m}$ only. Thus even in conventional launching method the launched ship, will never in grace the river channel as ear- marked by Kolkata Port Trust which is $350 \mathrm{~m}$ away from the land. However, in the proposed shipyard, since we shall adopt cradle plus winch type launching arrangement, the travel distance of the launched ship will be very little (around $350 \mathrm{~m}$ ) and in this case, there will never be any infringement in the river channel.

\section{Outfitting facilities for small vessels}

This zone is created on the northern side of the plot. A berthing pontoon of about $30 \mathrm{~m} \times 10 \mathrm{~m} \times 3.0 \mathrm{~m}$ will be parked at about $26 \mathrm{~m}$ away, from the northern boundary and $115 \mathrm{~m}$ from the eastern wall of the plot as shown in the plan. The pontoon will be kept in position by means heavy duty anchors (4nos) and duly tied up at bollards which will be grouted in the land. The schematic arrangement is shown in the plan. By the side of the pontoon it is proposed to perk 2 vessels $(55 \mathrm{mLx} 12 \mathrm{mBx} 3.5 \mathrm{mT})$ and one vessel $(97 \mathrm{mLx} 6 \mathrm{mBx} 2.5 \mathrm{mT})$ side by side, which will be duly tied up with the pontoon as well as on shore bollards. Gangway, consisting of fixed and movable portion will be arranged to make access to these vessels for movement of men and material. Other material will be carried by small dinghies. Under this situation the clear distance from shore edge of river channel earmarked for ships passage to the last vessel tied up with the pontoon will be $300 \mathrm{~m}$. Thus it is ensured that free movement of normal ships through the channel will not create any problem.

\section{Outfitting facilities for large vessels}

Another outfitting zone on the southern side of the plot of land is also created. A pontoon of about $60 \mathrm{~m} \times 15 \mathrm{~m} \times 3.0 \mathrm{~m}$ will be parked at about $250 \mathrm{~m}$ from the eastern wall near southern boundary of the plot as shown in the plan. The pontoon will be kept in position by heavy duty anchors (4nos.) duly tied up with pontoon and also will be tied up at bollards which will be grouted in the land. It is proposed to perk 2 vessels $(110 \mathrm{mLx} 25 \mathrm{mBx} 4 \mathrm{mT})$ and one vessel $(55 \mathrm{mLx} 12 \mathrm{mB}$ $\mathrm{x} 2.5 \mathrm{mT}$ ) side by side to the pontoon. Access for men and material movement to these ships, berthed on the pontoon will be arranged through gangway having fixed and moveable portions. Any other materials will be carried by small Dinghies. With this arrangement the clear distance of $210 \mathrm{~m}$ from the edge of navigation channel (for passage of ships) to the farthest vessel embarked, will be available. Thus the normal movement of ships through the river channel will be ensured all the time. 


\section{Outfitting facilities by canal side Jetty}

In future it is proposed to create permanent outfitting jetty on the side of the canal situated on the southern side of the plot as shown in the plan. A $10 \mathrm{M} \mathrm{m}$ wide jetty following the curvature of the canal shall be erected for regular repair of small boats. For this purpose captive dredging of the canal will be undertaken and a proper gate will be installed at the canal mouth in order to overcome the tidal variation. The proposed arrangement is also indicated in the plan. This will not ingress inside river, as such will not hinder movement of ships (Figure 5)

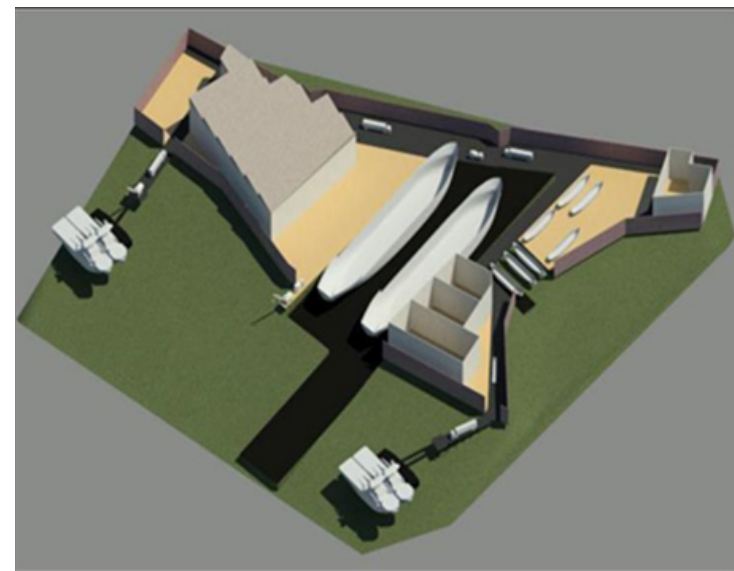

Figure 5 3D model of proposed shipyard.

\section{Material handling facility}

The movement of various material equipment, items inside the proposed shipyard will be generally in line with specific guidelines such as heavy items like Blocks, Engines, Gear boxes, Propellers, Gen set, Laundry equipment, Steering gear, and Switch Board will be transported on Tailor Engine. Medium size \& bulk items like full plates with parts, long sections, large seats, Electrical \& hydraulic panels, Insulations \& Paneling materials, lockers, doors etc will be sent to the destination in bulk quantity through Trucks. Small items like manholes furniture, hatches, seats, brackets, valves \& plumbing fitting, flanges, small electrical panels etc will be moved to various production areas by manual trolley. Adequate road linking production shops \& areas have been shown in the proposed layout of the Shipyard. The movement of fabricated items likes panels, sub-assemblies etc inside the shops will be handled by crane facilities of the respective shop. A level lofting moving crane on tracks will be located between erection bay \& block assembly bay for transportation of Blocks and other heavy materials, Engines, Gear Boxes, DG sets etc. ${ }^{1-5}$

\section{Conclusion}

An analytical \& technical appraisal has been presented in this report regarding Design of Layout of Greenfield Shipyard at Falta. From the study it is found that the proposed method is technically \& operationally feasible under the present site condition. Present layout has been designed for production capacity of 3large ships $(82 \mathrm{~m} \times 18 \mathrm{~m} \times 3.8 \mathrm{~m}$ or $105 \mathrm{~m} \times 30 \mathrm{mx} 4.5 \mathrm{~m})$ per annum \& 24 Small Crafts $(30 \mathrm{~m} \times 10 \mathrm{mx} 3 \mathrm{~m})$ per annum with till date modern facilities. However capacity of the yard may be increased based on future requirements which will lead to redesign of layouts. Situation may have to be reviewed if the design parameters and site parameters are drastically changed / reversed (Table 2).
Table 2 Production shops and stores

\begin{tabular}{|c|c|c|}
\hline Serial No & Location & Location ID \\
\hline I & Repair \& Outfitting Jetty & I \\
\hline 2 & Pre Outfitting Jetty & 2 \\
\hline 3 & Pipe Shop & 3 \\
\hline 4 & Electric Shop & 4 \\
\hline 5 & Paint Shop & 5 \\
\hline 6 & Launching Bay & 6 \\
\hline 7 & Winch House & 7 \\
\hline 8 & Gate Office at Gate 3 & 8 \\
\hline 9 & Crection Bay & 9 \\
\hline 10 & Block Assembly Bay & 10 \\
\hline 12 & Block Delivery Area & 12 \\
\hline 13 & Plate/Stiffner Bending/Forming & 13 \\
\hline 14 & Hull Fabrication shope II & 14 \\
\hline 15 & Gas Store & 15 \\
\hline 16 & Hull Store & 16 \\
\hline 17 & Work Store & 17 \\
\hline 18 & Supp. Off & 18 \\
\hline 19 & Weld Rod/Wire Store & 19 \\
\hline 20 & Weld Tool Store & 20 \\
\hline 21 & Hull Fabrication Shope I & 21 \\
\hline 22 & Gas Store Cum Distribution Area & 22 \\
\hline 23 & Compressor House & 23 \\
\hline 24 & $\begin{array}{l}\text { Flat Panel \& Stiffner Fabrication } \\
\text { Zone }\end{array}$ & 24 \\
\hline 25 & $\begin{array}{l}\text { Q.A.Office, Officer's Office Loft } \\
\text { ARE (Top) }\end{array}$ & 25 \\
\hline 26 & Open Area I & 26 \\
\hline 27 & Admin Building & 27 \\
\hline 28 & $\begin{array}{l}\text { Electrical Substation Electrical } \\
\text { Office }\end{array}$ & 28 \\
\hline 29 & Open Area II & 29 \\
\hline 30 & $\begin{array}{l}\text { Pantoon For Outfitting of } \\
\text { Small Ship }\end{array}$ & 30 \\
\hline 31 & $\begin{array}{l}\text { Pantoon For Outfitting } \\
\text { of Large Ship }\end{array}$ & 31 \\
\hline 32 & Fire Fighting & 32 \\
\hline & STN/Security Watch Tower & \\
\hline
\end{tabular}


Table Continued..

\begin{tabular}{|c|c|c|}
\hline Serial No & Location & Location ID \\
\hline 33 & $\begin{array}{l}4 \text { Storied Building Canteen/Toilet } \\
\text { / Rest Room for Workers \& } \\
\text { Supervisors, Boat Office }\end{array}$ & 33 \\
\hline 34 & $\begin{array}{l}\text { Steel Stockyard for Vertical } \\
\text { Storage of Steel Materials }\end{array}$ & 34 \\
\hline 35 & Scrap Yard & 35 \\
\hline 36 & Paint Store & 36 \\
\hline 37 & Oil Store & 37 \\
\hline 38 & $\begin{array}{l}\text { Cut Plate/Sections/Painted } \\
\text { Plate Temporary Store }\end{array}$ & 38 \\
\hline 39 & Shot Blast M/C Cum paint Bay & 39 \\
\hline 40 & CNC M/C Shop & 40 \\
\hline 41 & Raw Pipe Store & 41 \\
\hline 42 & Plumbling Fitting Store & 42 \\
\hline 43 & Bond Store & 43 \\
\hline 44 & Cable Store & 44 \\
\hline 45 & $\begin{array}{l}\text { GR.FLR. -Electrical Equipment } \\
\text { Store }\end{array}$ & 45 \\
\hline 46 & Ist FLR.-Electronic Store & 46 \\
\hline 47 & Engineering Equipment Store & 47 \\
\hline 48 & GR.-Wood /Furniture ect. & 48 \\
\hline $48 \mathrm{~A}$ & Ist -Insulation Item & $48 \mathrm{~A}$ \\
\hline 49 & GR. FLR.-Rope Winches ect. & 49 \\
\hline $49 \mathrm{~A}$ & Ist -Furniture/ Mattresses & $49 \mathrm{~A}$ \\
\hline 50 & $\begin{array}{l}\text { Plate Binding \& Small } \\
\text { Fabrication Shop }\end{array}$ & 50 \\
\hline 51 & Small Hardware Store & 51 \\
\hline
\end{tabular}

\section{Acknowledgments}

None.

\section{Conflicts of interest}

The author declares that there are no conflicts of interest.

\section{Funding}

None.

\section{References}

1. Shin Jong Gye, Song Young Joo, Lee Dong Kun, et al. A concept and framework for a shipyard layout design based on simulation. Journal of Ship Production. 2009;25(3):126-135.

2. Song, YJ Song, DG Lee, et al. System development and applications of a shipyard layout design framework, Journal of Ship Production and Design. 2010;26(2):144-154.

3. Proceedings of Shipbuilding Practice and Ship Design Methods Conference. 2001.

4. David GM Watson. Practical Ship Design (Google Books). 1998:531.

5. J Lyu. Design for Quality in the Shipbuilding Industry. International Journal of Quality \& Reliability Management. 1984. 